\title{
An In Vitro Effect of Triiodothyronine on Rat Adipose Tissue *
}

\author{
Martha Vaughan \\ (From the Laboratory of Metabolism, National Heart Institute, National Institutes of Health, \\ Bethesda, Maryland)
}

\begin{abstract}
Summary. Triiodo-L-thyronine $\left(\mathrm{T}_{3}\right)$ added in vitro to fat pads from normal, or propylthiouracil-treated rats enhanced the rate of release of glycerol and free fatty acids (FFA) in the presence of epinephrine. An effect of $T_{3}$ was also demonstrated in the presence of adrenocorticotropic hormone (ACTH), thyroid-stimulating hormone, or glucagon in studies with tissue from normal rats. The minimal effective concentration of $T_{3}$ was approximately $2.5 \times$ $10^{-5} \mathrm{~mole} / \mathrm{liter}$ for intact fat pads and $3 \times 10^{-6} \mathrm{~mole} / \mathrm{liter}$ for fat cells. With fat pads from propylthiouracil-treated rats the effect of $T_{3}$ was not apparent until the $3 \mathrm{rd} \mathrm{hr}$ of incubation. Enhancement of epinephrine-stimulated lipolysis by $T_{3}$ was evident during the $1 \mathrm{st} \mathrm{hr}$ of incubation of fat pads from normal rats, and fat cells responded almost immediately to the presence of $T_{3}$. When added alone or in the presence of theophylline, $3^{\prime}, 5^{\prime}$-adenosine monophosphate or its dibutyryl derivative, $T_{3}$ had little or no effect on lipolysis. The effect of $T_{3}$ was observed with or without glucose in the medium, and was not inhibited by cycloheximide or actinomycin $D$. It did not persist when tissues, after incubation in the presence of $T_{3}$ were transferred to medium without $T_{3}$. No effect of $T_{3}$ on glucose uptake in the presence of epinephrine, ACTH, or insulin was demonstrated.
\end{abstract}

\section{Introduction}

The release of free fatty acids (FFA) ${ }^{1}$ from adipose tissue in vitro and particularly the response of this process to epinephrine is markedly influenced by the thyroid status of the rats from which tissues are obtained (1-3). The lipolytic effect of epinephrine is diminished or even absent in tissues from hypothyroid rats and conversely is enhanced in tissues from animals injected with $T_{3}$. Bray and Goodman (4) have recently reported that increased sensitivity of the adipose tissue to epinephrine is demonstrable as early as $3 \mathrm{hr}$

* Submitted for publication 25 April 1966; accepted 7 June 1967.

Address requests for reprints to Dr. Martha Vaughan, Laboratory of Metabolism, National Heart Institute, Bethesda, Md. 20014.

1 Abbreviations used are: FFA, free fatty acids; $T_{3}$, triiodo-L-thyronine; PTU, propylthiouracil; ACTH, adrenocorticotropic hormone; TSH, thyroid-stimulating hormone. after the intravenous administration of $T_{3}$ to thyroidectomized rats. This and the effect on heart rate, which may also be the result of an altered sensitivity to catecholamines, were evident before other changes (e.g., in body temperature or cardiac glycogen). Thus, the effect of $T_{3}$ in adipose tissue may in fact be representative of an important primary action of thyroid hormones which occurs in several tissues and which may lead secondarily to other characteristic metabolic changes. The experiments reported below were undertaken to demonstrate and to study directly, in vitro, the effect of $T_{3}$ on lipolysis in adipose tissue as a first step toward elucidating the mechanism of the action of thyroid hormone which has been described as a sensitization to the effects of catecholamines.

\section{Methods}

Epididymal fat pads were obtained from SpragueDawley rats that had been allowed free access to food until they were decapitated. Incubation of tissues and 
TABLE I

Effect of $T_{3}$ and related compounds on release of glycerol

\begin{tabular}{|c|c|c|c|c|c|}
\hline \multirow[b]{3}{*}{ Addition concn } & \multirow{3}{*}{$\begin{array}{l}\text { No. of } \\
\text { pairs }\end{array}$} & \multicolumn{4}{|c|}{ Glycerol released } \\
\hline & & \multicolumn{2}{|c|}{$0-3 \mathrm{Hr}$ (no epinephrine) } & \multicolumn{2}{|c|}{ 3-4 Hr (plus epinephrine) } \\
\hline & & Control & $\Delta$ due to addition* & Control & $\Delta$ due to addition* \\
\hline & & \multicolumn{4}{|c|}{$\mu$ moles $/ \mathrm{g}$} \\
\hline Triiodo-L-thyronine, $2.5 \times 10^{-5}$ mole $/$ liter & 12 & 5.3 & $+1.6 \pm 1.19$ & 3.6 & $+1.5 \pm 0.31 \ddagger$ \\
\hline L-Diiodoty-rosine, $3.7 \times 10^{-5} \mathrm{~mole} / \mathrm{liter}$ & 12 & 3.5 & $+0.3 \pm 0.57$ & 2.7 & $-0.1 \pm 0.19$ \\
\hline $\begin{array}{l}\mathrm{D}, \mathrm{L}-\text { Tetrachlorothyronine, } \\
\quad \text { mole/liter }\end{array}$ & 6 & 4.9 & $+0.9 \pm 0.54$ & 5.0 & $-0.4 \pm 1.00$ \\
\hline
\end{tabular}

Paired fat pads, incubated in $3 \mathrm{ml}$ of Krebs' bicarbonate medium containing bovine serum albumin, $30 \mathrm{mg} / \mathrm{ml}$, one with and one without addition as indicated. After $3 \mathrm{hr}$ a sample of medium was removed for determination of glycerol. Epinephrine (final concentration $0.1 \mu \mathrm{g} / \mathrm{ml}$ ) was added and incubation was continued for another hour.

* Mean of differences between pairs \pm SE of the mean.

$\ddagger P<0.001$.

quantification of FFA, glycerol, and glucose in the medium were carried out as described in earlier publications from this laboratory $(5,6)$.

Fat cells were prepared essentially as described by Rodbell (7). Incubation with collagenase was carried out in Krebs-Ringer phosphate medium, containing serum albumin, $30 \mathrm{mg} / \mathrm{ml}$, in an atmosphere of air. Glycerol was determined in samples of cells plus medium with glycerokinase and $\alpha$-glycerophosphate dehydrogenase in a one step procedure devised by Chernick, ${ }^{2}$ but modified so that $\mathrm{NADH}$ was quantified by measuring absorption at $340 \mathrm{~m} \mu$. The amount of fat cells used in each experiment was calculated from the amount of heptane-extractable hydroxamate-reactive (8) ester assuming that 3 meq ester $=1 \mathrm{mg}$ cells.

Epinephrine solutions were prepared from the bitartrate. Concentrations are expressed as the free base. Thyroid-stimulating hormone (TSH) was a gift from Dr. Peter Condliffe. ACTH $(100 \mathrm{U} / \mathrm{mg})$ was purchased from Calbiochem (Los Angeles, California). Crystalline glucagon was obtained from Eli Lilly \& Co. (Indianapolis, Ind.) through the courtesy of Dr. O. K. Behrens. Two preparations of sodium triiodo-L-thyronine were used. One from Calbiochem was used for injection and some in vitro studies, and another one from Smith, Kline \& French Laboratories (Philadelphia, $\mathrm{Pa}$.) was used for most in vitro experiments. L-Thyroxin was a product of Glaxo Laboratories, Ltd. (Greenford, England). Cyclic 3',5'-adenosine monophosphate (AMP) was purchased from the Sigma Chemical Co. (St. Louis, Mo.) and ${ }^{\circ} \mathrm{N}-2^{\prime}$-O-dibutyryl cyclic $3^{\prime}, 5^{\prime}$-AMP prepared by Dr. T. Posternak was a gift from Dr. R. W. Butcher.

Propylthiouracil (PTU)-treated rats had received drinking water containing $0.05 \%$ propylthiouracil for $3-5$ wk. Controls for the PTU-treated animals consisted of rats from the same litters, housed in adjacent cages. All animals received Purina Chow pellets ad lib. For injection, sodium triiodo- $L$-thyronine was dissolved in a small volume of $0.1 \mathrm{~N} \mathrm{NaOH}$ and then diluted with saline

2 S. S. Chernick. Personal communication. so that the concentration of $\mathrm{NaOH}$ in the solution injected was less than $0.002 \mathrm{~N}$. Rats were given $200 \mu \mathrm{g}$ of $\mathrm{T}_{3}$ by intraperitoneal injection $19 \mathrm{hr}$ and again $3 \mathrm{hr}$ before the experiment. Control animals received injections of solvent alone.

\section{Results}

Effects of $T_{3}$ in the presence of epinephrine or other fat-mobilizing hormone. $\mathrm{T}_{3}$ caused no stimulation of glycerol release during the $3 \mathrm{hr}$ of incubation in medium alone as shown in Table $I$. When epinephrine was added to all flasks during the 4th $\mathrm{hr}$, however, the tissues in medium that contained $\mathrm{T}_{3}$ released significantly more glycerol than did the controls. Most of the FFA was released during the 4th $\mathrm{hr}$, after epinephrine was present, and a significant effect of $T_{3}$ on the total was observed (not included in the Table). Diiodotyrosine and tetrachlorothyronine in similar molar concentrations were without effect on release of glycerol (or of FFA) whether or not epinephrine was present.

The first experiment in Table II shows again the lack of effect of $T_{3}$ added alone on glycerol release. In the presence of epinephrine, $0.5 \mu \mathrm{g} / \mathrm{ml}$ an effect of $\mathrm{T}_{3}$ on release of glycerol and FFA was observed in each of the $4 \mathrm{hr}$ of incubation. In Experiment 3, with tissues from PTU-treated rats incubated with epinephrine there was also a significant effect of $T_{3}$ on glycerol release but only in the 3rd and 4th $\mathrm{hr}$. It will be noted that the release of glycerol (and of FFA) from these tissues in the presence of epinephrine was distinctly lower than that observed with the tissues from 
TABLE II

Effect of triicdothyronine $\left(T_{3}\right)$ on release of glycerol and $F F A$

\begin{tabular}{|c|c|c|c|c|c|c|}
\hline \multirow{2}{*}{$\begin{array}{l}\text { Expt. } \\
\text { No. }\end{array}$} & \multirow[b]{2}{*}{ Additions } & \multirow[b]{2}{*}{$\mathrm{Hr}$} & \multicolumn{2}{|c|}{ Glycerol released } & \multicolumn{2}{|c|}{ FFA released } \\
\hline & & & Control & $\Delta$ due to $\mathrm{T}_{\mathrm{8}} *$ & Control & $\Delta$ due to $\mathrm{T}_{3} *$ \\
\hline & & & \multicolumn{2}{|c|}{$\mu$ moles $/ g$ per $\mathrm{hr}$} & \multirow{2}{*}{\multicolumn{2}{|c|}{$\begin{array}{l}\mu e q / g \text { per } h r \\
+0.2 \pm 0.31 \\
+0.8 \pm 0.38 \\
+1.4 \pm 0.66 \\
+0.4 \pm 0.30\end{array}$}} \\
\hline 1 & None & $\begin{array}{l}1 \\
2 \\
3 \\
4\end{array}$ & $\begin{array}{l}3.3 \\
3.2 \\
3.1 \\
1.5\end{array}$ & $\begin{array}{r}0 \pm 0.39 \\
+0.3 \pm 0.86 \\
+0.4 \pm 0.57 \\
+0.4 \pm 0.71\end{array}$ & & \\
\hline 2 & Epinephrine, $0.5 \mu \mathrm{g} / \mathrm{ml}$ & $\begin{array}{l}1 \\
2 \\
3 \\
4\end{array}$ & $\begin{array}{l}5.6 \\
5.3 \\
3.6 \\
4.4\end{array}$ & $\begin{array}{l}+1.8 \pm 0.54 \ddagger \\
+1.8 \pm 0.64 \ddagger \\
+2.0 \pm 0.56 \ddagger \\
+1.6 \pm 0.43 \ddagger\end{array}$ & $\begin{array}{l}3.6 \\
8.9 \\
7.3 \\
9.1\end{array}$ & $\begin{array}{l}+2.4 \pm 0.52 \ddagger \\
+4.4 \pm 1.10 \ddagger \\
+3.5 \pm 1.02 \ddagger \\
+2.3 \pm 0.74 \ddagger\end{array}$ \\
\hline 3 & $\begin{array}{l}\text { Epinephrine, } 0.5 \mu \mathrm{g} / \mathrm{ml} \\
\text { PTU-treated rats }\end{array}$ & $\begin{array}{l}1 \\
2 \\
3 \\
4\end{array}$ & $\begin{array}{l}1.6 \\
1.3 \\
1.1 \\
1.4\end{array}$ & $\begin{array}{r}0 \pm 0.09 \\
+0.4 \pm 0.17 \\
+0.7 \pm 0.20 \ddagger \\
+0.6 \pm 0.17 \ddagger\end{array}$ & $\begin{array}{l}0.6 \\
1.3 \\
1.6 \\
1.6\end{array}$ & $\begin{array}{l}+0.4 \pm 0.12 \ddagger \\
+0.9 \pm 0.27 \ddagger \\
+1.0 \pm 0.28 \ddagger \\
+1.5 \pm 0.42 \ddagger\end{array}$ \\
\hline 4 & $\begin{array}{l}\text { Epinephrine, } 0.5 \mu \mathrm{g} / \mathrm{ml} \\
95 \% \mathrm{~N}_{2}-5 \% \mathrm{CO}_{2}\end{array}$ & $\begin{array}{l}1 \\
2 \\
3\end{array}$ & $\begin{array}{l}1.6 \\
1.4 \\
1.7\end{array}$ & $\begin{array}{l}+0.8 \pm 0.40 \\
+1.4 \pm 0.42 \ddagger \\
+1.0 \pm 0.31 \ddagger\end{array}$ & $\begin{array}{l}1.4 \\
2.1 \\
3.1\end{array}$ & $\begin{array}{l}+1.6 \pm 0.60 \ddagger \\
+2.4 \pm 0.80 \ddagger \\
+2.3 \pm 0.66 \ddagger\end{array}$ \\
\hline 5 & Epinephrine, $0.5 \mu \mathrm{g} / \mathrm{ml}$ & $\begin{array}{l}1 \\
2\end{array}$ & & & $\begin{array}{l}4.3 \\
8.4\end{array}$ & $\begin{array}{l}+2.1 \pm 0.50 \ddagger \\
+3.0 \pm 1.06 \ddagger\end{array}$ \\
\hline 6 & $\begin{array}{l}\text { Epinephrine, } 0.5 \mu \mathrm{gg} / \mathrm{ml} \\
\text { glucose, } 1 \mathrm{mg} / \mathrm{ml}\end{array}$ & $\begin{array}{l}1 \\
2\end{array}$ & & & $\begin{array}{l}2.2 \\
5.9\end{array}$ & $\begin{array}{l}+2.0 \pm 0.43 \ddagger \\
+2.5 \pm 0.63 \ddagger\end{array}$ \\
\hline
\end{tabular}

Paired fat pads from normal fed rats (except Expt. 3) were incubated in $3 \mathrm{ml}$ of Krebs' bicarbonate medium containing bovine serum albumin, $30 \mathrm{mg} / \mathrm{ml}$, and other additions as indicated, in an atmosphere of $95 \% \mathrm{O}_{2}-5 \% \mathrm{CO}_{2}($ except Expt. 4). To one of each pair $\mathrm{T}_{3}$ was added in a final concentration of $2.5 \times 10^{-5} \mathrm{~mole} / \mathrm{liter}$. After incubation for 1 hr each tissue was removed from the medium, rapidly rinsed twice, gently blotted, replaced in a flask containing fresh medium of identical composition to be incubated for another hour, and samples of used medium were taken for determination of glycerol and free fatty acids (FFA). Each mean includes data from six pairs of tissues, except that for Expt. 2, $\mathrm{hr} 1 \mathrm{FFA}$ based on five pairs. The rats used in Expt 3 had received drinking water containing $0.05 \%$ of propylthiouracil for $5 \mathrm{wk}$ before the experiment.

* Mean of differences between pairs $\pm \mathrm{SE}$ of the mean.

$\ddagger P<0.05$.

TABLE III

Effect of $T_{3}$ on glycerol release stimulated by epinephrine $(E)$ in tissues from PTU-treated rats

\begin{tabular}{|c|c|c|c|c|c|}
\hline \multirow[b]{3}{*}{ Rats (No.) } & \multicolumn{4}{|c|}{ Glycerol released } & \multirow[b]{3}{*}{ Hr 3 vs. hr 1} \\
\hline & \multicolumn{2}{|c|}{$1 \mathrm{st} \mathrm{hr}$} & \multicolumn{2}{|c|}{$\begin{array}{c}3 \mathrm{rd} \mathrm{hr} \text { (medium with } \mathrm{T}_{3} \text { for } \\
\text { PTU-treated) }\end{array}$} & \\
\hline & No $E$ & $\Delta$ due to $E^{*}$ & No $E$ & $\Delta$ due to $\mathrm{E}^{*}$ & \\
\hline & \multicolumn{2}{|c|}{ umoles $/ \mathrm{g}$ per $\mathrm{hr}$} & \multicolumn{2}{|c|}{ 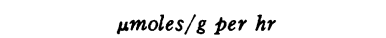 } & \\
\hline Control (6) & $1.2+0.17$ & $+2.6 \pm 0.49$ & $0.6 \pm 0.10$ & $+3.3 \pm 0.64$ & NS \\
\hline PTU-treated (11) & $1.1 \pm 0.12$ & $+0.8 \pm 0.28$ & $0.5 \pm 0.09$ & $+2.4 \pm 0.45$ & $P<0.01$ \\
\hline Control vs. PTU-treated & & $P<0.005$ & & NS & \\
\hline
\end{tabular}

Propylthiouracil (PTU)-treated rats had been given drinking water containing $0.05 \%$ of propylthiouracil for $23-26$ days before the experiment. Fat pads from control rats weighed 338-664 mg, those from PTU-treated rats weighed 208-512 mg. Paired fat pads were incubated in $3 \mathrm{ml}$ of Krebs' bicarbonate medium containing bovine serum albumin, $30 \mathrm{mg} / \mathrm{ml}$, one of each pair with and one without epinephrine, $0.15 \mu \mathrm{g} / \mathrm{ml}$. After $1 \mathrm{hr}$ the tissues were rapidly rinsed, blotted, and placed in fresh medium. The medium in which the tissues from PTU-treated rats were incubated contained $\mathrm{T}_{3}, 3.7 \times 10^{-5} \mathrm{~mole} / \mathrm{liter}$, that for control tissues did not. At the end of the $2 \mathrm{nd} \mathrm{hr}$ tissues were again rinsed, blotted, and placed in fresh medium (containing $T_{3}$ for the experimental tissues). To one of each pair of tissues epinephrine, $0.15 \mu \mathrm{g} / \mathrm{ml}$, was added. The data on FFA release paralleled those for glycerol and are therefore not included in the Table.

NS, not significant.

* Mean of differences between pairs $\pm \mathrm{SE}$ of the mean. 
TABLE IV

Effect of $T_{3}$ and L-thyroxine on release of glycerol in the presence of $A C T H$ or TSH

\begin{tabular}{|c|c|c|c|c|}
\hline \multirow[b]{2}{*}{ Expt. No. } & \multirow[b]{2}{*}{ Addition Concn } & \multirow[b]{2}{*}{$\mathrm{Hr}$} & \multicolumn{2}{|c|}{ Glycerol released } \\
\hline & & & Control & $\Delta$ due to addition* \\
\hline ACTH, $0.2 \stackrel{1}{U / m l}$ in all flasks & $\begin{array}{l}\text { Triiodo-L-thyronine, } \\
2.5 \times 10^{-5} \text { mole/liter }\end{array}$ & $\begin{array}{l}1 \\
2 \\
3 \\
4\end{array}$ & $\begin{array}{l}9.0 \\
6.4 \\
4.2 \\
4.2\end{array}$ & $\begin{array}{l}\text { les } / g \text { per } h r \\
+2.0 \pm 0.55 \ddagger \\
+1.2 \pm 0.33 \ddagger \\
+1.4 \pm 0.27 \ddagger \\
+2.3 \pm 0.61 \ddagger\end{array}$ \\
\hline ACTH, $0.2 \stackrel{2}{U / m l}$ in all flasks & $\begin{array}{l}\text { L-Thyroxine, } \\
5 \times 10^{-5} \text { mole/liter }\end{array}$ & $\begin{array}{l}1 \\
2\end{array}$ & $\begin{array}{l}7.8 \\
5.0\end{array}$ & $\begin{array}{l}+0.4 \pm 0.90 \\
+0.7 \pm 0.15 \ddagger\end{array}$ \\
\hline TSH, $10 \mu g / m l$ in all flasks & $\begin{array}{l}\text { Triiodo-L-thyronine, } \\
2.5 \times 10^{-5} \text { mole/liter }\end{array}$ & $\begin{array}{l}1 \\
2\end{array}$ & $\begin{array}{l}7.1 \\
7.2\end{array}$ & $\begin{array}{l}+1.7 \pm 0.47 \ddagger \\
+1.4 \pm 0.30 \ddagger\end{array}$ \\
\hline
\end{tabular}

ACTH, adrenocorticotropic hormone; TSH, thyroid-stimulating hormone.

Experiments were carried out as described in the legend to Table II. In Expts. 1 and 2 all flasks contained ACTH, $0.2 \mathrm{U} / \mathrm{ml}$; in Expt. 3, TSH, $10 \mu \mathrm{g} / \mathrm{ml}$. Each mean includes data from six pairs of tissues.

$*$ Mean of differences between paired tissues $\pm \mathrm{SE}$ of the mean.

$\ddagger P<0.05$.

normal rats in Experiment 2. Table III summarizes data from a different type of experiment showing again the effect of $T_{3}$ on the sensitivity to epinephrine of tissue from PTU-treated rats. Pairs of fat pads were incubated first for $1 \mathrm{hr}$, one of each pair with and one without epinephrine. The basal release of glycerol and FFA was not significantly different in the control and PTUtreated groups but the response to epinephrine was significantly lower in the tissues from PTUtreated rats. During the $2 \mathrm{nd} \mathrm{hr}$ the control tissues were incubated in medium alone and the tissues from PTU-treated rats in medium containing $\mathrm{T}_{3}$. During the 3rd hr the effect of epinephrine was again determined in medium containing $T_{3}$ for the experimental tissues, and in medium without $\mathrm{T}_{3}$ for the control tissues. The epinephrine effect on glycerol (and FFA) release by the PTU-treated tissues in the presence of $T_{3}$ was significantly higher than it was in the 1 st $\mathrm{hr}$ and was as great as that in the control tissues during the $3 \mathrm{rd}$ hr.

In Experiment 4 of Table II the incubations were carried out in an atmosphere of $95 \%$ nitrogen and the release of FFA and glycerol in the presence of epinephrine alone was lower than it was in 95\% oxygen (Experiment 2), but an effect of $\mathrm{T}_{3}$ was still demonstrable. The effect of $T_{8}$ on FFA release was not altered by the presence of glucose, $1 \mathrm{mg} / \mathrm{ml}$, in the incubation medium as shown in Experiments 5 and 6 (Table II) carried out at the same time with tissues from the same group of rats.
An effect of $T_{3}$ on release of glycerol was demonstrable also in the presence of ACTH or TSH (Table IV). Thyroxine, $5 \times 10^{-5}$ mole/liter, caused a significant stimulation of glycerol release in the presence of $\mathrm{ACTH}$, in the second but not during the 1 st hr of incubation. Release of FFA paralleled that of glycerol in all instances and the data are, therefore, not included in the Table.

Table $\mathrm{V}$ shows the effect of several different concentrations of $T_{3}$ in the presence of ACTH or epinephrine. The lowest concentration of $T_{3}$ that has been found effective under these experimental conditions is $1.2 \times 10^{-5} \mathrm{~mole} / \mathrm{liter}$. Higher concentrations, up to $1.25 \times 10^{-4} \mathrm{~mole} / \mathrm{liter}$ do not appear to be more effective. When tissues are rinsed and transferred to medium containing epinephrine but no $T_{3}$ the effect of $T_{3}$ does not persist, at least not long enough to influence sig-

TABLE V

Effect of concentration of triiodothyronine on release of glycerol

\begin{tabular}{|c|c|c|c|c|}
\hline \multirow[b]{2}{*}{ Expt. No. } & \multirow{2}{*}{$\begin{array}{c}T_{3} \text { Concn } \\
M \times 10^{5}\end{array}$} & \multirow[b]{2}{*}{$\mathrm{Hr}$} & \multicolumn{2}{|c|}{ Glycerol released } \\
\hline & & & No $T_{3}$ & $\Delta$ due to $T_{3}$ \\
\hline & & & \multicolumn{2}{|c|}{$\mu$ moles $/ \mathrm{g}$ per $\mathrm{hr}$} \\
\hline 1 & 1.2 & 1 & 10.0 & $+2.2 \pm 0.48$ \\
\hline \multirow{3}{*}{$\begin{array}{l}\text { ACTH, } 0.2 U / \mathrm{ml}, \\
\text { in all flasks }\end{array}$} & 6.2 & 2 & 5.8 & $+3.2 \pm 0.43$ \\
\hline & 12.5 & 3 & 5.9 & $+2.8 \pm 0.62$ \\
\hline & 0 & 4 & 5.8 & $+0.8 \pm 0.66$ \\
\hline 2 & 6.2 & 1 & 6.6 & $+1.6 \pm 0.51$ \\
\hline \multirow{3}{*}{$\begin{array}{l}\text { Epinephrine, } 0.5 \mu \mathrm{g} / \mathrm{ml} \text {, } \\
\text { in all flasks }\end{array}$} & 2.5 & 2 & 5.7 & $+1.7 \pm 0.30$ \\
\hline & 0.6 & 3 & 4.5 & $-0.4 \pm 0.30$ \\
\hline & $\mathbf{0}$ & 4 & 3.0 & $-0.2 \pm 0.39$ \\
\hline
\end{tabular}

Experiments were carried out as described in legend for Table I, with tissues transferred each hour to fresh medium, one of each pair without and one with $T_{z}$ in the concentration indicated. 
TABLE VI

Effect of $T_{3}$ on glycerol production by fat cells in the presence of epinephrine or glucagon

\begin{tabular}{|c|c|c|}
\hline Expt. No & $\underset{M \times 10^{6}}{T_{8} \text { Concn }}$ & Glycerol produced \\
\hline & & $\underset{\text { per } 30 \mathrm{~min} *}{\mu m o l e s / g}$ \\
\hline $\begin{array}{l}1 \\
\text { Epinephrine, } 0.01 \mu \mathrm{g} / \mathrm{ml} \\
\text { in all flasks }\end{array}$ & $\begin{array}{c}0 \\
6.2 \\
15.4\end{array}$ & $\begin{array}{r}3.0 \pm 0.92 \\
7.0 \pm 1.05 \\
13.5 \pm 1.05\end{array}$ \\
\hline $\begin{array}{l}2 \\
\text { Epinephrine, } 0.01 \mu \mathrm{g} / \mathrm{ml} \\
\quad \text { in all flasks }\end{array}$ & \begin{tabular}{r}
\multicolumn{1}{c}{0} \\
3.1 \\
7.7 \\
15.4
\end{tabular} & $\begin{array}{l}10.5 \pm 0.23 \\
13.7 \pm 0.38 \\
13.4 \pm 0.86 \\
15.3 \pm 0.22\end{array}$ \\
\hline $\begin{array}{l}3 \\
\text { Glucagon, } 0.1 \mu \mathrm{g} / \mathrm{ml} \\
\text { in all flasks }\end{array}$ & $\begin{array}{l}0 \\
6.2\end{array}$ & $\begin{array}{l}14.0 \pm 0.91 \\
17.8 \pm 0.36\end{array}$ \\
\hline
\end{tabular}

The incubation period was started when fat cells $(50-60$ $\mathrm{mg}$ in $0.5 \mathrm{ml}$ of medium) were added to plastic vials containing $2 \mathrm{ml}$ of Krebs-Ringer phosphate medium with bovine serum albumin, $30 \mathrm{mg} / \mathrm{ml}$, and other additions as indicated. Samples $(0.5 \mathrm{ml})$ of cells plus medium were removed at zero time and at 15 -min intervals thereafter for assay of glycerol. Incubation was carried out at $37^{\circ} \mathrm{C}$. There was no measurable glycerol production $(<1.0 \mu \mathrm{mole} /$ $\mathrm{g}$ per $\mathrm{hr}$ ) by cells incubated without epinephrine or glucagon, whether or not $T_{3}$ was present.

${ }^{*}$ Mean $\pm \mathrm{SE}$ of mean. In Expt. 1 and 3, $n=3$; in Expt. 2, $n=4$.

nificantly the total amount of glycerol or FFA released during the subsequent hour.

In experiments with fat cells the minimal effective concentration was somewhat lower. In Experiment 1, Table VI, the rate of glycerol production was unusually low in the presence of epinephrine, $0.01 \mu \mathrm{g} / \mathrm{ml}$ and the effect of $\mathrm{T}_{3}$ was very striking. In Experiment 2 the same concentration of epinephrine produced a greater acceleration of lipolysis and the effect of $T_{3}$, although demonstrable even at $3.1 \times 10^{-6} \mathrm{~mole} / \mathrm{liter}$, was much smaller. It is apparent that if the rate of lipolysis is maximal in the absence of $\mathrm{T}_{3}$ no effect of the hormone will be demonstrable. Similarly, the higher the rate of lipolysis the smaller the potential maximal effect of $T_{3}$. In the experiment shown in Fig. 1, the effect of $T_{3}$ was much greater in the presence of $0.01 \mu \mathrm{g}$ of epinephrine per $\mathrm{ml}$ than it was with $0.02 \mu \mathrm{g}$ of epinephrine per $\mathrm{ml}$. The rate of glycerol release was approximately doubled by doubling the concentration of epinephrine and was more than doubled by the addition of $T_{3}$ in the presence of the smaller amount of epinephrine. An effect of $T_{3}$ has also been observed with fat cells incubated in the presence of glucagon (Tables VI and VIII) or ACTH (not shown).

Experiments with cyclic AMP and theophylline. With intact fat pads a small but significant effect of $\mathrm{T}_{3}$ was observed in the presence of cyclic $3^{\prime}, 5^{\prime}$ AMP, or ${ }^{6} \mathrm{~N}-2^{\prime}-O$-dibutyryl cyclic AMP, but not in the presence of $5^{\prime}$-AMP (Table VII). The reason for the small negative effect of $T_{3}$ in the 1st $\mathrm{hr}$ of Experiment 4 (Table VII) is not known and it has not been observed in any oth $r$ similar experiments. In only one experiment out of nine has it been possible to observe an effect of $T_{3}$ on glycerol release in the presence of theophylline and in this experiment (No. 5 in Table VII) there was no significant enhancement of FFA release.

In several experiments with fat cells, no effect of $\mathrm{T}_{3}$ has been demonstrated in the presence of $3^{\prime}, 5^{\prime}$-AMP or of theophylline, although in the same experiment enhancement of glycerol production by cells incubated with hormone was observed. Data from one such experiment are summarized in Table VIII. Incubations were carried out in Krebs-Ringer phosphate medium and in medium from which $\mathrm{Ca}^{++}, \mathrm{Mg}^{++}$, and $\mathrm{K}^{+}$

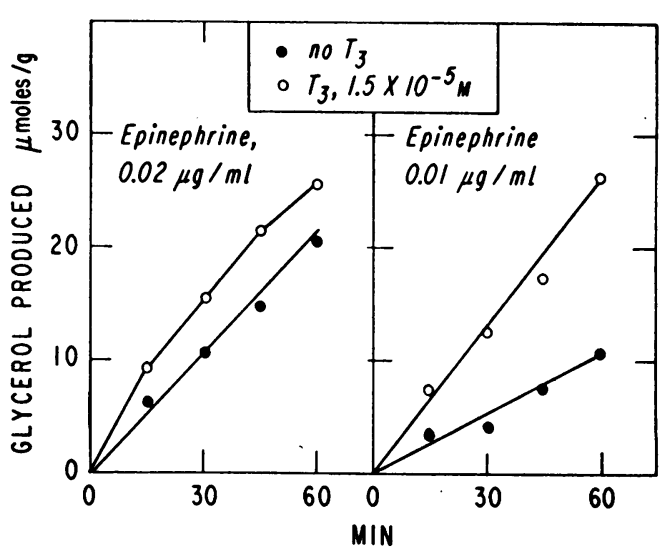

Fig. 1. EFFect of $T_{3}$ ON GLYCEROL PRODUCtION BY FAT CELLS IN THE PRESENCE OF EPINEPHRINE. Fat cells (69 $\mathrm{mg}$ in $0.5 \mathrm{ml}$ of Krebs-Ringer phosphate medium with bovine serum albumin, $30 \mathrm{mg} / \mathrm{ml}$ ) were added to plastic vials containing $2 \mathrm{ml}$ of the same medium with other additions as indicated. Samples $(0.5 \mathrm{ml})$ of cells plus medium were taken after $15,30,45$, and $60 \mathrm{~min}$ for assay of glycerol. Zero time values have been subtracted. Cells incubated without epinephrine, whether or not $T_{8}$ was present, produced $<1.5 \mu$ moles of glycerol/g per $\mathrm{hr}$. Three vials were incubated under each set of conditions, and in all cases the findings were in close agreement. 
TABLE VII

Effect of $T_{3}$ on release of glycerol and FFA in the presence of $3^{\prime}, 5^{\prime}-A M P$ or theophylline

\begin{tabular}{|c|c|c|c|c|c|c|}
\hline \multirow{2}{*}{$\begin{array}{l}\text { Expt } \\
\text { No. }\end{array}$} & \multirow[b]{2}{*}{ Additions } & \multirow[b]{2}{*}{$\mathbf{H r}$} & \multicolumn{2}{|c|}{ Glycerol released } & \multicolumn{2}{|c|}{ FFA released } \\
\hline & & & No $T_{3}$ & $\Delta$ due to $T_{3} *$ & No $T_{3}$ & $\Delta$ due to $T_{2} *$ \\
\hline 1 & 3',5'-AMP, $1 \mu \mathrm{mole} / \mathrm{ml}$ & 1 & 1.7 & $\begin{array}{l}\mu \text { moles } / g \\
+0.3\end{array} \pm 0.09 \ddagger$ & 0.3 & $\begin{array}{l}\mu \text { moles } / \mathrm{g} \\
\quad+0.2 \pm 0.04 \ddagger\end{array}$ \\
\hline 2 & $\begin{array}{l}\text { None } \\
3^{\prime}, 5^{\prime} \text {-AMP, } 5 \text { mmoles } / \mathrm{ml}\end{array}$ & 2 and 3 & $\begin{array}{l}2.2 \\
2.0\end{array}$ & $\begin{array}{ll}+0.2 & \pm 0.10 \\
+0.8 & \pm 0.18 \ddagger\end{array}$ & $\begin{array}{l}0 \\
0.9\end{array}$ & $+1.0 \pm 0.21 \ddagger$ \\
\hline 3 & $\begin{array}{l}6 N-2 \text {-0-dibutyryl cyclic AMP, } \\
0.5 \mu \text { moles } / m l\end{array}$ & 1 and 2 & 5.2 & $+1.6 \pm 0.32 \ddagger$ & 1.6 & $+0.8 \pm 0.26 \ddagger$ \\
\hline 4 & $\begin{array}{l}\text { None } \\
\text { 5'AMP, } 5 \text { umoles } / \mathrm{ml}\end{array}$ & 2 and 3 & $\begin{array}{l}1.4 \\
4.2\end{array}$ & $\begin{array}{l}-0.25 \pm 0.06 \ddagger \\
-0.3 \pm 0.16\end{array}$ & $\begin{array}{l}\mathbf{0} \\
\mathbf{0}\end{array}$ & $\begin{array}{l}\mathbf{0} \\
\mathbf{0}\end{array}$ \\
\hline 5 & Theophylline, $1 \mu$ mole $/ \mathrm{ml}$ & $1-3$ & 6.2 & $+0.4 \pm 0.05 \ddagger$ & 7.6 & $+0.5 \pm 0.20$ \\
\hline 6 & Theophylline, $1 \mu$ mole $/ \mathrm{ml}$ & $1-3$ & 7.6 & $+0.6 \pm 0.45$ & 3.9 & $+0.3 \pm 0.33$ \\
\hline 7 & $\begin{array}{l}\text { None } \\
\text { Theophylline, } 0.5 \mu \text { moles } / \mathrm{ml}\end{array}$ & $\begin{array}{l}1 \\
2\end{array}$ & $\begin{array}{l}1.8 \\
7.2\end{array}$ & $\begin{array}{l}+0.4 \pm 0.32 \\
-0.4 \pm 0.90\end{array}$ & $\begin{array}{l}0 \\
7.0\end{array}$ & $\begin{array}{c}0 \\
-1.5 \pm 1.16\end{array}$ \\
\hline
\end{tabular}

Pairs of fat pads were incubated, one with and one without $T_{3}\left(3.7 \times 10^{-5}\right.$ mole/liter in all experiments except No. 4 , in which it was $2.5 \times 10^{-5} \mathrm{~mole} /$ liter). Additions when made were present in all flasks. In Expts. 2, 4, and 7 tissues were rinsed, blotted, and transferred at the end of $1 \mathrm{hr}$ to fresh medium containing additions as indicated. There were six pairs of tissues in each experiment.

* Mean of differences between paired tissues $\pm \mathrm{SE}$ of the mean.

$+P<0.05$.

were omitted because it has been found that stimulation of lipolysis by $3^{\prime}, 5^{\prime}$-AMP is much greater in the latter medium than it is in medium containing $\mathrm{Ca}^{++}, \mathrm{Mg}^{++}$, and $\mathrm{K}^{+}$. 3 The effect of glucagon was less in medium in which $\mathrm{Na}^{+}$was the only cation than it was in the complete medium, but an effect

3 Mosinger, B., and M. Vaughan. The action of cyclic $3^{\prime}, 5^{\prime}$ adenosine monophosphate on lipolysis in rat adipose tissue. Biochim. Biophys. Acta. In press.

\section{TABLE VIII}

Effect of $T_{3}$ on glycerol production by fat cells in the presence of glucagon, theophylline, or $3^{\prime}, 5^{\prime}-A M P$

\begin{tabular}{|c|c|c|c|c|}
\hline \multirow[b]{3}{*}{$\begin{array}{l}\text { Addition } \\
\text { concn }\end{array}$} & \multicolumn{4}{|c|}{ Glycerol produced } \\
\hline & \multicolumn{2}{|c|}{ Complete medium } & \multicolumn{2}{|c|}{$\mathrm{No} \mathrm{Ca}^{++}, \mathrm{Mg}^{++}, \mathrm{K}^{+}$} \\
\hline & No $T_{8}$ & $\begin{array}{l}\Delta \text { due } \\
\text { to } T_{3}\end{array}$ & No $T_{3}$ & $\begin{array}{l}\Delta \text { due } \\
\text { to } T_{3}\end{array}$ \\
\hline \multirow[b]{2}{*}{$\begin{array}{l}\text { Glucagon, } 0.05 \\
\mu \mathrm{g} / \mathrm{ml}\end{array}$} & \multicolumn{4}{|c|}{ umoles $/ g$ per 30 min } \\
\hline & 12.4 & +5.0 & 7.4 & +3.9 \\
\hline $\begin{array}{l}\text { Theophylline, } \\
10^{-4} \text { moles/liter }\end{array}$ & 17.1 & +0.5 & 14.8 & +1.0 \\
\hline $3^{\prime}, 5^{\prime}$-AMP, $10^{-3}$ & 2.2 & +0.2 & 8.6 & +0.6 \\
\hline
\end{tabular}

The experiment was carried out as described in the legend for Table VII. Complete medium was Krebs-Ringer phosphate medium. The other medium consisted of 104 parts $0.154 \mathrm{M} \mathrm{NaCl}$ and 12 parts. $0.1 \mathrm{M}$ sodium phosphate buffer. Both media contained bovine serum albumin $30 \mathrm{mg} / \mathrm{ml}$; final pH 7.2. Two samples of cells were incubated under each set of conditions and in all cases the values agreed closely. The concentration of $T_{3}$ was $6.2 \times 10^{-6}$ mole/liter. Glycerol production in either medium with or without $T_{2}$ was less than $1.0 \mu \mathrm{mole} / \mathrm{g}$ per $30 \mathrm{~min}$ in the absence of other additions. of $T_{3}$ was evident in both. No effect of $T_{3}$ was observed in either medium in the presence of $3^{\prime}, 5^{\prime}$ AMP or theophylline.

As shown in Table IX, the effect of cyclic AMP, $5 \mu \mathrm{moles} / \mathrm{ml}$ on glycerol release was not significantly greater in tissues from rats that had been treated with $T_{3}$ although the tissues from $T_{3}$ treated rats released significantly more glycerol and FFA than did the controls in the absence of cyclic AMP, and the effect of cyclic AMP on FFA release was somewhat higher in the experimental group.

TABLE IX

Effect of cyclic $3^{\prime}, 5^{\prime}-A M P$ on tissues from $T_{3}$ treated rats

\begin{tabular}{|c|c|c|c|c|}
\hline \multirow[b]{2}{*}{ Rats } & \multicolumn{2}{|c|}{ Glycerol released } & \multicolumn{2}{|c|}{ FFA released. } \\
\hline & $\begin{array}{l}\text { No cyclic } \\
\text { AMP* }\end{array}$ & $\begin{array}{c}\Delta \text { due to } \\
\text { cyclic AMP } \ddagger\end{array}$ & $\begin{array}{l}\text { No cyclic } \\
\text { AMP* }\end{array}$ & $\begin{array}{c}\Delta \text { due to } \\
\text { cyclic AMP }\end{array}$ \\
\hline & \multicolumn{2}{|c|}{ umoles $/ \mathrm{g}$} & \multicolumn{2}{|c|}{$\mu e q / g$} \\
\hline Control & $1.1+0.14$ & $+1.0 \pm 0.20$ & $-0.2 \pm 0.07$ & $+0.4 \pm 0.14$ \\
\hline$T_{3}$-treated & $2.8 \pm 0.29$ & $+1.6 \pm 0.36$ & $1.5 \pm 0.32$ & $+1.4 \pm 0.34$ \\
\hline$T_{3}$ vs. control & $P<0.005$ & & $P<0.01$ & $P<0.05$ \\
\hline
\end{tabular}

Six $T_{3}$-treated rats received $200 \mu \mathrm{g}$ of $T_{3}$ intraperitoneally $21 \mathrm{hr}$ and again $3 \mathrm{hr}$ before the experiment. Six control rats were injected with the same volume of the solvent. Pairs of fat pads were incubated for $2 \mathrm{hr}$, one of each pair with and one without cyclic $3^{\prime}, 5^{\prime}$-AMP, $5 \mu$ moles/ ml. Fat pads from, control rats weighed 160-379 mg. Those from $T_{3}$-treated rats weighed $153-363 \mathrm{mg}$

$*$ Mean \pm SE of the mean.

$\ddagger$ Mean of differerices between paired tissues \pm SE of the mean. 
TABLE $\mathrm{X}$

Effect of cycloheximide $(C)$ on release of glycerol and FFA

\begin{tabular}{|c|c|c|c|c|c|}
\hline \multirow[b]{2}{*}{ Additions } & \multirow[b]{2}{*}{$\mathrm{Hr}$} & \multicolumn{2}{|c|}{ Glycerol released } & \multicolumn{2}{|c|}{ FFA released } \\
\hline & & No $C$ & $\Delta$ due to $C^{*}$ & No C & $\Delta$ due to $C^{*}$ \\
\hline & & & oles $/ \mathrm{g}$ & & $\mu e q / g$ \\
\hline None & 1 & 3.4 & $+0.2 \pm 0.21$ & 2.0 & $+0.3 \pm 0.08$ \\
\hline $\begin{array}{l}\mathrm{T}_{3}, 2.5 \times 10^{-5} \text { mole } / \text { liter } \\
\quad \text { and epinephrine, } 0.5 \mu \mathrm{g} / \mathrm{ml}\end{array}$ & $\begin{array}{l}2 \\
3\end{array}$ & $\begin{array}{r}10.4 \\
7.5\end{array}$ & $\begin{array}{l}+0.2 \pm 0.30 \\
-0.1 \pm 0.32\end{array}$ & $\begin{array}{l}11.4 \\
11.4\end{array}$ & $\begin{array}{l}+0.3 \pm 0.64 \\
+0.7 \pm 1.13\end{array}$ \\
\hline
\end{tabular}

Six pairs of fat pads incubated, one with and one without cycloheximide $(C), 155 \mu \mathrm{g} / \mathrm{ml}$; transferred each hour to fresh medium that contained other additions as indicated in all flasks.

* Mean of differences between pairs \pm SE of the mean.

Effect of inhibitors of protein synthesis on the response to $T_{3}$. As shown in Table $\mathrm{X}$, cycloheximide, $155 \mu \mathrm{g} / \mathrm{ml}$ did not alter the rate of glycerol release due to $\mathrm{T}_{3}$ plus epinephrine, even when present for $1 \mathrm{hr}$ before the two hormones were added. (This concentration of cycloheximide markedly inhibited the effect of growth hormone plus dexamethasone on glycerol and FFA release in parallel experiments.)

In another experiment six pairs of tissues were incubated for $3 \mathrm{hr}$ in medium containing $\mathrm{T}_{3}, 2.5 \times$ $10^{-5} \mathrm{~mole} /$ liter. Epinephrine, $0.5 \mu \mathrm{g} / \mathrm{ml}$ was added for the $3 \mathrm{rd} \mathrm{hr}$. Throughout the incubation period one of each pair of tissues was exposed also to actinomycin D, $20 \mu \mathrm{g} / \mathrm{ml}$. Actinomycin D had no effect on the amount of glycerol or FFA released during the $3 \mathrm{hr}$ incubation period.

Effect of $T_{3}$ on glucose uptake. In the first ex- periment in Table XI there was a small effect of $\mathrm{T}_{3}$ (of borderline significance) on glucose uptake in the presence of epinephrine. In several other similar experiments in which conditions (e.g., glucose concentration) were varied slightly no effect of $T_{3}$ on glucose uptake could be demonstrated although a significant effect on FFA release was obtained. Data from a similarly negative experiment in the presence of $\mathrm{ACTH}$ are included also in Table $\mathrm{X}$. There was a significant effect of $\mathrm{T}_{3}$ on FFA release but not on glucose uptake. Nor was it possible to demonstrate an effect of $\mathrm{T}_{3}$ on glucose uptake in the presence of insulin, 1 or $10 \mathrm{mU} / \mathrm{ml}$.

\section{Discussion}

Debons and Schwartz (1) reported several years ago the failure to demonstrate an in vitro

TABLE XI

Effect of $T_{3}$ on glucose uptake in the presence of epinephrine or ACTH

\begin{tabular}{|c|c|c|c|c|}
\hline Expt. No. & Conditions & $\begin{array}{l}\text { No. of } \\
\text { pairs }\end{array}$ & Glucose uptake & FFA released \\
\hline $1 \mathrm{~A}$ & $\begin{array}{l}\text { No epinephrine } \\
\Delta \text { due to epinephrine* }\end{array}$ & 4 & $\begin{array}{c}m g / g \text { per } 2 \mathrm{hr} \\
2.75 \\
+1.55 \pm 0.48\end{array}$ & $\begin{array}{c}\mu e q / g \text { per } 2 \mathrm{hr} \\
0 \\
+6.7^{ \pm} \pm 1.03\end{array}$ \\
\hline $\begin{array}{l}\text { B } \\
\text { Epinephrine, } 1 \mu g / m l \\
\text { in all flasks }\end{array}$ & $\begin{array}{l}\text { No } \mathrm{T}_{3} \\
\Delta \text { due to } \mathrm{T}_{3}^{*}\end{array}$ & 6 & $\begin{array}{c}3.74 \\
+0.50 \pm 0.15\end{array}$ & $\begin{array}{c}7.8 \\
+7.4 \pm 0.68\end{array}$ \\
\hline $2 \mathrm{~A}$ & $\begin{array}{l}\text { No ACTH } \\
\Delta \text { due to ACTH* }\end{array}$ & 4 & $\begin{array}{c}4.49 \\
+1.64 \pm 0.13\end{array}$ & $\begin{array}{c}0 \\
+11.3 \\
\pm 1.46\end{array}$ \\
\hline $\begin{array}{l}\text { B } \\
\text { ACTH, } 0.2 U / m l \\
\text { in all flasks }\end{array}$ & $\begin{array}{l}\text { No } T_{3} \\
\Delta \text { due to } T_{3}^{*}\end{array}$ & 6 & $\begin{array}{c}7.24 \\
-0.07 \pm 0.75\end{array}$ & $\begin{array}{c}9.0 \\
+4.0 \pm 0.97\end{array}$ \\
\hline
\end{tabular}

The Krebs' bicarbonate medium contained bovine serum albumin, $30 \mathrm{mg} / \mathrm{ml}$, and glucose, $1.5 \mathrm{mg} / \mathrm{ml}$. Each experiment was comprised of four pairs of tissues, one incubated with and one without epinephrine, $1 \mu \mathrm{g} / \mathrm{ml}$, or $\mathrm{ACTH}, 0.2$ $\mathrm{U} / \mathrm{ml}$, and six pairs of tissues incubated with epinephrine or ACTH in all flasks and $\mathrm{T}_{3}, 2.5 \times 10^{-5} \mathrm{~mole} / \mathrm{liter}$ in one of each pair.

* Mean of differences between paired tissues $\pm \mathrm{SE}$ or the mean. 
effect of $T_{3}$ on rat adipose tissue. There were a number of differences between their experiments and those reported here (e.g., size of rats, treatment of fat pads before incubation, and concentration of epinephrine). The most important difference undoubtedly was that the concentrations of $\mathrm{T}_{3}$ employed were lower than those required to produce an effect in our study. Because it has been reported $(9,10)$ that the effect of $T_{3}$ (or $\mathrm{T}_{4}$ ) on epinephrine stimulated contraction of rabbit aortic strips in vitro is probably due to chelation of copper in the incubation medium, it is important to note that the effects of $\mathrm{T}_{3}$ on adipose tissue (fat pads or cells) in vitro are not mimicked by EDTA. At concentrations of $10^{-4}-10^{-6}$ mole/ liter under the conditions used in experiments with $\mathrm{T}_{3}$, EDTA was without effect on lipolysis when added alone, with epinephrine and/or $\mathrm{T}_{3}$. At higher concentrations and under different conditions EDTA does have effects on lipolysis but they are quite unlike those of $\mathrm{T}_{3}{ }^{3}$

The effects of $T_{3}$, added to adipose tissue in vitro, reported above resemble in several ways those observed in tissues from rats treated with $\mathrm{T}_{3}$. Although both glycerol and FFA release are elevated in fat pads from $T_{3}$-treated rats $(1,3)$ the bulk of the evidence indicates that it is the response to epinephrine rather than the basal lipolytic activity that is most affected by the thyroid hormones. Similarly in vitro, $T_{3}$ was for the most part without effect on release of glycerol or FFA when present alone. Bray and Goodman (4) found that increased sensitivity of the adipose tissue to epinephrine was demonstrable $3 \mathrm{hr}$ after intravenous injection of $T_{3}$ in thyroidectomized rats. In the studies reported above, there was no significant effect of $T_{3}$ on tissues from PTU. treated rats until the $3 \mathrm{rd} \mathrm{hr}$ of incubation, although in the tissues from normal rats the effect of $T_{3}$ added in vitro was apparent during the $1 \mathrm{st} \mathrm{hr}$ and fat cells from normal rats appeared to respond almost immediately. The latent period for the effect of thyroxine in vivo was longer than that for $\mathrm{T}_{3}$ (4) and in this regard it may be significant that an effect of thyroxine added in vitro to tissues from normal rats was not observed until the 2nd hr of incubation.

The effect of $T_{3}$ on lipolysis in adipose tissue has often been referred to as one of sensitizing the tissue to the action of catecholamines. As shown above, however, a similar effect of $T_{3}$ is observed also in the presence of ACTH, TSH, or glucagon, and it has recently been reported that the lipolytic effects of ACTH, TSH, and glucagon are reduced in fat pads from thyroidectomized rats (11). These findings indicate that the effect of $T_{3}$ is not specifically related to catecholamines and suggest a site of action in a pathway influenced by all of these hormones.

The enhancement of lipase activity caused by epinephrine, ACTH, TSH, glucagon, or theophylline is believed to be secondary to an increase in the intracellular concentration of $3^{\prime}-5^{\prime}$-AMP (12), produced in the case of the hormones by stimulation of synthesis of the cyclic nucleotide and in the case of theophylline by inhibition of its degradation. In the presence of theophylline the concentration of cyclic AMP in fat pads may rise to higher levels than those attained with hormone treatment and apparently maximal rates of lipolysis are observed. Hynie, Krishna, and Brodie (13), found that, in the presence of $5 \times 10^{-3} \mathrm{M}$ theophylline, tissues from normal, hypo-, or hyperthyroid rats all released glycerol at the same rate. They assumed that with this high concentration of theophylline, lipase activation was complete and concluded that the total amount of lipase was unaffected by thyroid status. Brodie et al. (14) also reported that adipose tissue from thyroidectomized rats did not differ from that of normal rats in lipolytic response to theophylline at several concentrations, i.e., the "sensitivity" of the tissue to theophylline was not altered by thyroid status. The failure to demonstrate an effect of $T_{3}$ in vitro in the presence of theophylline (in concentrations expected to produce a less than maximal effect on lipolysis) is quite compatible with these earlier observations. Within the framework of current hypothesis it is probably reasonable to conclude that $T_{3}$ does not alter the total amount of lipase in adipose tissue, nor does it influence the amount of $3^{\prime}, 5^{\prime}$-AMP accumulated in the presence of theophylline or the lipolytic response to the nucleotide.

Presumably then, $T_{3}$ acts in some way to increase the amount of $3^{\prime}, 5^{\prime}$-AMP that accumulates when adenyl cyclase activity is stimulated by one of the so-called lipolytic hormones. This could be brought about by inhibition of degradation of the nucleotide and if this were the case it might be 
difficult to demonstrate an effect of $\mathrm{T}_{3}$ in the presence of theophylline which is believed to act by inhibiting the cyclic-AMP phosphodiesterase. Theophylline, however, is effective in the absence of a lipolytic hormone and $T_{3}$ is not, so that whatever their respective mechanisms of action may be, they are clearly different. Essentially all of the observations on the effects of $T_{3}$ on adipose tissue (as well as those effects in other tissues that have been described as sensitization to catecholamines) could be explained by an action of $T_{3}$ on the adenyl cyclase system such that its responsiveness to hormonal stimulation is enhanced. Brodie et al. (14) reported that adenyl cyclase activity was higher in adipose tissue from rats that had been treated for 5 days with thyroxine than it was in tissue from control animals, although it has not been demonstrated that the amount of adenyl cyclase is increased by thyroid hormones. Thyroxine has been shown to stimulate protein synthesis in other systems (15) but the in vitro effect of $\mathrm{T}_{3}$ on adipose tissue appears not to be dependent on protein synthesis since it occurs very rapidly and is not inhibited by cycloheximide or actinomycin $\mathrm{D}$.

Interpretation of experiments with $3^{\prime}, 5^{\prime}$-AMP added to the medium in vitro is complicated by the fact that the added nucleotide often does not mimic the effects of the lipolytic hormones and in fact under certain conditions may counteract them (16). ${ }^{3}$ Nevertheless, the very small or absent effect of $T_{3}$ added in vitro in the presence of $3^{\prime}, 5^{\prime}$ AMP is consonant with the failure to observe an increased lipolytic response to the nucleotide in tissues from rats treated with $T_{3}$, and the results of both types of experiments are compatible with the hypothesis that $T_{3}$ acts by enhancing the stimulatory action of the so-called lipolytic hormones on adenyl cyclase. ${ }^{4}$

It has not been demonstrated that stimulation of glucose uptake by epinephrine (or by ACTH) is mediated by cyclic AMP. Under certain condi-

\footnotetext{
4 In an experiment with fat pads from thyroidectomized rats incubated for $3 \mathrm{hr}$, one of each pair of tissues with and one without $T_{3}\left(2.5 \times 10^{-5}\right.$ mole/liter $)$, phosphorylase activity after $3 \mathrm{~min}$ of exposure to epinephrine was significantly higher in the tissues that had been incubated with $T_{3}$ than it was in the control tissues. This observation would not be explained by an effect of $T_{8}$ specifically on the lipolytic system or its activation but is quite consistent with an effect on the adenyl cyclase system.
}

tions the effects of the hormones on lipolysis and on glucose uptake can be dissociated. Goodman and Bray (11) found that the effect of epinephrine on oxidation of glucose- $\mathrm{U}-{ }^{14} \mathrm{C}$ was not influenced by the thyroid status of the animals from which tissues were obtained. Similarly, $T_{3}$ added in vitro was without effect on glucose uptake in the presence of epinephrine or ACTH although at the same time it caused a significant stimulation of FFA release. It has been reported that the effect of insulin on glucose uptake is enhanced in adipose tissue from hyperthyroid rats (17). The failure to observe an effect of $T_{3}$ added in vitro on glucose uptake in the presence of insulin could mean that this is an effect of $T_{3}$ that is not related to the cyclic AMP system and which takes longer to develop, or it might mean simply that the experimental conditions were not suitable for demonstrating this effect.

Qualitatively, there are certainly several similarities in the effects on adipose tissue of $T_{3}$ administered in vivo and in vitro. Even the concentration that caused an essentially maximal effect with fat cells in vitro was not very different from the blood levels that might be reached after intravenous administration of $45 \mu \mathrm{g}$ of $\mathrm{T}_{3}$ to rats (4). It is the time course of the appearance and disappearance of the in vitro $\mathrm{T}_{3}$ effect that differs most obviously from that of the hormones injected in vivo. In evaluating the significance of this difference the basic question seems to be whether the latent period and the persistence of the effect of $T_{3}$ administered in vivo reflect time required for alterations in the activity of effector systems influenced by $T_{3}$ or whether they are related to the rate of uptake, extent of accumulation and rate of degradation, or perhaps release, of thyroid hormones by fat cells. If it is the former, one would have to conclude that the in vitro and in vivo effects of $T_{3}$, although apparently alike in so many ways, are in fact produced by different mechanisms. On the other hand, when considered in terms of the second alternative there are numerous obvious differences between the conditions in vitro and in vivo that might account for the findings. For example, in vitro the medium contains serum albumin as the only added protein but in plasma there are several proteins in addition to albumin that bind $T_{3}$. In vivo, all fat cells are more or less equally exposed to circulating $T_{3}$ whereas 
when a fat pad is incubated in vitro only the cells at the surface may be directly and immediately exposed to the hormone. In any case, until more is known about this aspect of the action of $T_{3}$ it is difficult to assess the significance of the rapid appearance and disappearance of the in vitro effect. On the basis of the qualitative similarities between the effects of $T_{3}$ in vitro and in vivo it seems quite probable that they are mediated in similar fashion.

\section{Acknowledgment}

The expert technical assistance of Mrs. F. Lieberman and Miss S. Stanley is gratefully acknowledged.

\section{References}

1. Debons, A. F., and I. L. Schwartz. 1961. Dependence of the lipolytic action of epinephrine in vitro upon thyroid hormone. J. Lipid Res. 2: 86.

2. Felt, V., B. Schovanec, P. Benes, F. Plzak, and V. Vrbensky. 1962. The effect of thyroid state, adrenaline and glucose on the release of free fatty acids from adipose tissue. Experientia. 18: 379.

3. Deykin, D., and M. Vaughan. 1963. Release of free fatty acids by adipose tissue from rats treated with triiodothyronine or propylthiouracil. J. Lipid Res. 4: 200.

4. Bray, G. A., and H. M. Goodman. 1965. Studies on early effects of thyroid hormones. Endocrinology. 76: 323 .

5. Vaughan, M. 1961. Effect of hormones on glucose metabolism in adipose tissue. J. Biol. Chem. 236: 2196.

6. Vaughan, M. 1962. The production and release of glycerol by adipose tissue incubated in vitro. $J$. Biol. Chem. 237 : 3354.

7. Rodbell, M. 1964. Metabolism of isolated fat cells:
I. Effects of hormones on glucose metabolism and lipolysis. J. Biol. Chem. $239: 375$.

8. Snyder, F., and N. Stephens. 1959. A simplified spectrophotometric determination of ester groups in lipids. Biochim. Biophys. Acta. 34: 244.

9. Shemano, I., and P. C. Fallon. 1960. Effect of L-3, 3',5-triiodothyronine on epinephrine-induced contraction of isolated rabbit aortic strip. Proc. Soc. Exptl. Biol. Med. 103: 282.

10. Shida, H., M. A. Meyers, and S. B. Barker. 1963. Effect of copper in thyroxine potentiation of in vitro epinephrine action on smooth muscle. $J$. Pharmacol. Exptl. Therap. 141: 280.

11. Goodman, H. M., and G. A. Bray. 1966. Role of thyroid hormones in lipolysis. Am. J. Physiol. 210: 1053.

12. Butcher, R. W., R. J. Ho, H. C. Meng, and E. W. Sutherland. 1965. Adenosine 3',5'-monophosphate in biological materials. II. The measurement of adenosine $3^{\prime}, 5^{\prime}$-monophosphate in tissues and the role of the cyclic nucleotide in the lipolytic response of fat to epinephrine. J. Biol. Chem. 240: 4515.

13. Hynie, S., G. Krishna, and B. B. Brodie. 1965. Theophylline, a tool for the study of the interaction of thyroid and sympathetic systems in hormone-induced lipolysis. Federation Proc. 24: 188.

14. Brodie, B. B., J. I. Davis, S. Hynie, G. Krishnan, and B. Weiss. 1966. Interrelationships of catecholamines with other endocrine systems. Pharmacol. Rev. 18: 273.

15. Sokoloff, L., and S. Kaufman. 1961. Thyroxine stimulation of amino acid incorporation into protein. J. Biol. Chem. 236: 795.

16. Dole, V. P. 1961. Effect of nucleic acid metabolites on lipolysis in adipose tissue. J. Biol. Chem. 236: 3125 .

17. Hagen, J. H. 1960. Effect of insulin on the metabolism of adipose tissue from hyperthyroid rats. J. Biol. Chem. 235 : 2600. 